\title{
STUDY OF SOME PARAMETERS AFFECTING SPRAY DISTRIBUTION UNIFORMITY PATTEREN
}

\author{
E. M. E. Sehsah ${ }^{*}$ and S. Kleisinger ${ }^{* *}$
}

\begin{abstract}
One of the most important requirements on agricultural boom sprayers is to produce a uniform distribution of the applied pesticide on the target area. In the agricultural pesticide applied by the sprayers, there are some main factors effects on the distribution of spray. The major factors affecting on the pattern of the liquid spray is the wind speed (cross-flow), height of boom and nozzle pressure. The current research carried out in the laboratory of the Institute of Agricultural Engineering, Hohenheim University, Germany. The aims of the present research was to investigate of the effect of the cross wind speed on the pattern of liquid spray and study the interaction between the wind speed, the height of boom, type of nozzles and nozzle pressure and their effects on the spray of pattern.

The electrical axial fan of $2.2 \mathrm{~kW}$ was used to produce the cross wind speed of 1.2 and 3.1m s.1. The IDKN120-04, AD110-03, TT11003 Turbo Jet and ATR 208 (Albus) spray nozzles were used at different nozzle pressures. Tests were conducted in the laboratory using an experimental spray patternator with 150 collection tubes (3 meters wide) at three nozzle pressures of 300, 400 and $500 \mathrm{kPa}$ for IDKN Lechler, TT11004 and Turbo Jet nozzle at wind speeds 1.2 and $3.1 \mathrm{~m} \mathrm{~s}^{-1}$ of the trajectory of liquid and without wind speed $\left(0 \mathrm{~m} \mathrm{~s}^{-1}\right)$. The nozzle pressures for ATR208 (Albus) nozzle were 300, 400, and $500 \mathrm{kPa}$ at the same wind conditions. Results indicated that the wind speed affected the uniformity of dose under laboratory conditions. The IDKN120-04 nozzle gave the low effect compared to the others nozzles.

Dr. Sehsah, El-Sayed El-Beily, Dept. of Agric. Eng. Faculty of Agricultural Kafr El-Sheikh, Kafr 1-Sheikh University, 33516-kafr El-Sheikh, Egypt E-Mail sehsah_2000@yahoo.de

**Prof. Dr. Siegfried Kleisinger, University of Hohenheim, Institute of Agricultural Engineering, (440) VIK, 70599-stuttgart, Germany, E-Mail kleisinger@uni-hohenheim.de
\end{abstract}


The nozzle height and nozzle pressure had a high significant effect on the uniformity of spray. The highest mean value of $17.3 \%$ for the SPD was found at the ATR 208 nozzle, nozzles height of $60 \mathrm{~cm}$, nozzle pressures of $300 \mathrm{kPa}$ and wind speed of $3.1 \mathrm{~m} \mathrm{~s}^{-1}$.

The minimum mean value of $0.8 \%$ for the SPD was found at the IDKN120-04 nozzle, nozzles height of $30 \mathrm{~cm}, \mathrm{kPa}$, nozzle pressures of 300 and wind speed of $1.2 \mathrm{~m} \mathrm{~s}^{-1}$. In addition, the maximum SPD \% for the other nozzles at nozzle height of $60 \mathrm{~cm}$, wind speed of $3.1 \mathrm{~ms}^{-1} 3.1$ and nozzle pressure $300 \mathrm{kPa}$ were 10. r, 7.9, and $1.1 \%$ for the AD110-03, TT110-03 Tee-jet and IDKN110-04 nozzle respectively.

Key words: Wind, distribution, spray, nozzles.

\section{INTRODUCTION}

basic approach to select a spray based on the pattern and other
spray characteristics needed, generally, yields good results. The
spray selection should be considered early in the design of the system. Although spray nozzle manufacturers are capable of producing nozzles to suit virtually any requirement, it is good practice to select the sprays and set the spray parameters based on what is readily available. Special spray nozzle requirements will likely cause needless delay in a project, considering that the spectrum of standardized sprays currently in existence is so large.

Distribution measurements can also take place on an actual farm or turf sprayer. For static measurements along the sprayer boom, a patternator equal or very similar to the one described earlier is placed under the boom in a stationary position. A distribution quality test gives the applicator important information about the state of the nozzles on the boom. When it has much more detailed information about spray quality and coverage are required, a dynamic system spraying a tracer (dye) can be used. Koch and Weisser (1996) clearly demonstrated the importance of dynamic factors; they stated that, spray distribution, measured under static conditions on a patternator, does not represent the pattern achieved in routine dynamic applications. Each specific sprayer configuration defined by nozzle type, spraying height, pressure and speed yields in a specific horizontal dynamic distribution pattern that is unpredictable and shows tangential strips of distinct deposit levels on targets within the sprayed area. 
Deposition can vary more than $80 \%$ and the average actual quantity of deposit was normally much lower than that calculated because of fan geometry and spray losses outside the sprayed area. To avoid misinterpretation, when dose response was investigated, it was necessary to identify the specific dynamic transversal distribution pattern of any sprayer configuration used in tests in order to as sure that dose levels within the sprayed area were known and can be related to target positions below or between nozzle positions. They also stated that the prediction of deposition on targets from distribution measurements on a patternator was an assumption rather than a scientifically proven result.

Krishnan et al. (2005) studied the effects of spray boom deflection, wind velocity, and wind direction on spray pattern displacement (SPD) of extended range of 110-0 fan nozzles by using a patternator. Tests were conducted at four nozzle pressures of 139, 208, 313 and $383 \mathrm{kPa}$. At each pressure, tests were conducted at four wind conditions (including combinations of both cross and head wind), two spray boom deflections of 0.2 and $0.4 \mathrm{~m}$ amplitude, and a frequency of $1 \mathrm{~Hz}$. spray boom deflection, wind velocity and wind direction significantly $(\mathrm{P}<0.05)$ affected SPD values at 139-, 208-, and 313-kPa nozzle pressure. However, coefficient of variation (C.V., \%) values of $8.5 \%$ to $13.5 \%$ obtained from these tests indicated uniform or acceptable coverage. In addition, the SPD values of $5.2 \%$ to $10.2 \%$ obtained from these tests indicated excellent spray distribution for the range of the treatments tested. There is some evidence to suggest that head winds have the greatest effect on changing (C.V., \%) in the field compared to that the laboratory, particularly with smaller droplets, with these contributing to increased vortices around the sprayer structure. Recent work at BBA (Herbst and Wolf, 2001) showed different C.V.( \%) ranges were found for mounted and trailed sprayers. Ghosh and. Hunt (1998) indicated that the forward movement of the tractor induces a relative cross-wind (typically with velocities $U_{x 0}$ in the range of 3 to $5 \mathrm{~m} \mathrm{~s}^{-1}$ ), which together with any natural wind (With velocity, $U_{y 0}$, that in practice has to be less than $U_{x 0}$ ). The affects of spray are in two ways, first, by bending over and distorting the vertical air jet induced by the spray and secondly, by deflecting the larger droplets. 
Holland et al (1997) showed that altering droplet trajectories away from the vertical (which will, generally, worsen coefficient of variation measurements on horizontal patternators in the laboratory was beneficial in improving spray deposition. Below the nozzle, the friction between the spray droplets and the air results in an entrained wind directed downward (Briffa and Dombrowski, 1966).

\section{MATERIALS AND METHODS}

The cross-flow was simulated in the laboratory to study the effect of wind speed (cross-flow) on the spray distribution, because it is difficult to control the cross wind under field conditions. The cross wind (cross-flow) may be produced by the forward movement of the tractor or as a nature cross-flow of wind as shown in Fig. 1. The Mechanical patternator of 3 meter width was used under laboratory condition in the Institute of Agriculture Engineering, Hohenheim University, Germany. Initially, the pattern data collection was attempted using the traditional method, i.e. using a mechanical patternator as shown in Fig. 2. The patternator consisted of 150 collection Plexiglas's tubes and the tube has $20 \mathrm{~mm}$ diameter and $50 \mathrm{~cm}$ height. The all treatments and the technical measuring data for the different nozzles were indicated in table1.

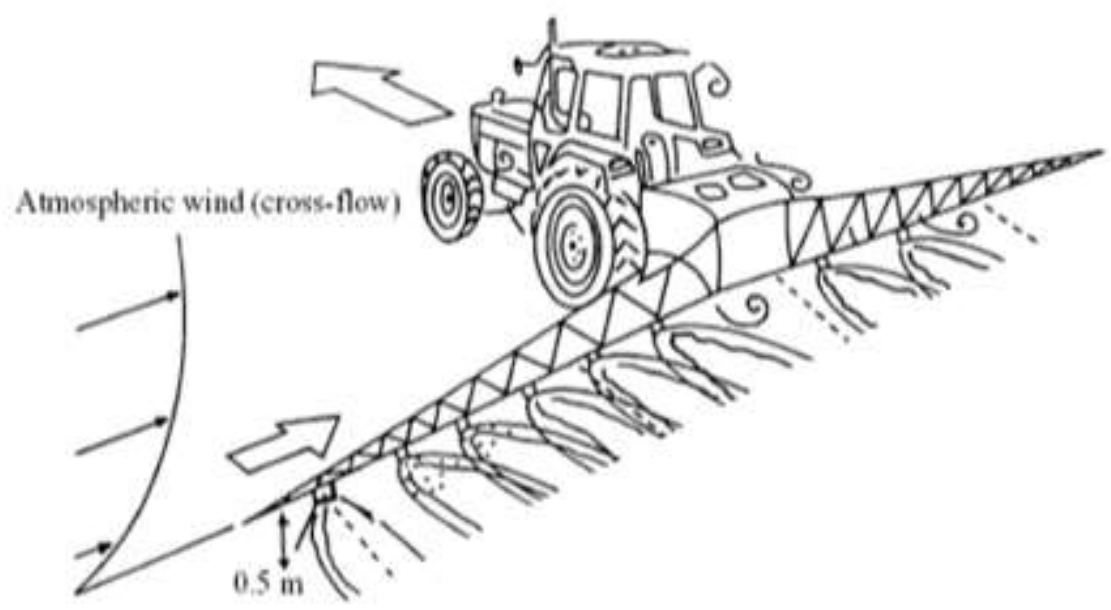

Fig. 1: The diagram of agricultural sprayers drawn by a tractor moving at a forward speed in cross-flow with wind velocity

Facilities and measurements 
The IDKN120-04 (Lechler nozzle), TT110-03 Turbo-Jet (Tee-Jet nozzle), AD110-03 (Lechler nozzle), and ATR208 (Albus nozzle) were selected at different boom height of 30 and $60 \mathrm{~cm}$. The nozzles were mounted on a 1axis traverse and held in place by a using a clamp assembly.

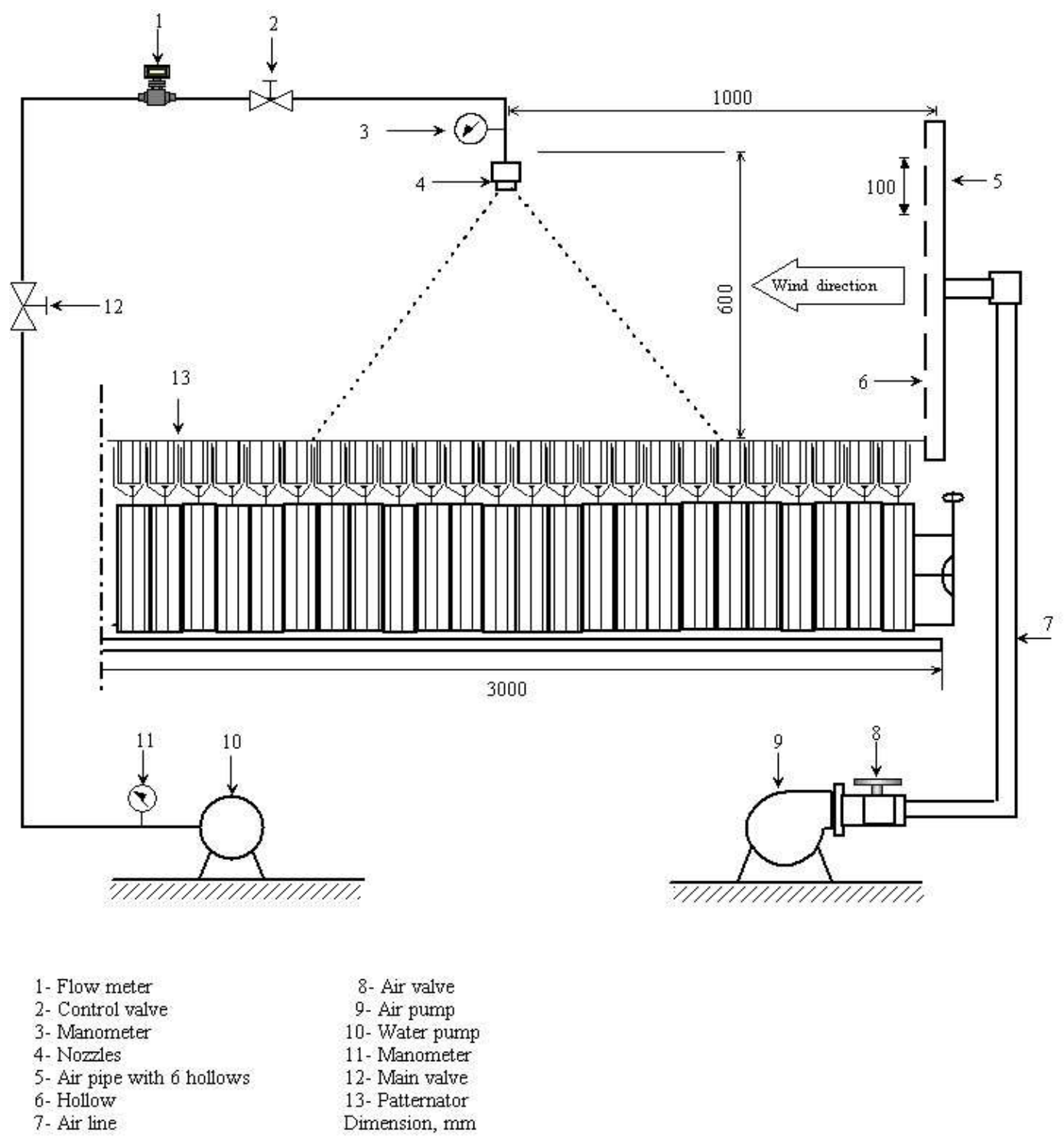

Fig.2: Diagram of the patternator with the facilities and instrument to measure the distribution of nozzles 
Liquid flow to the nozzle was delivered using a pressurized vessel; the GPI Electronic Digital Turbine Meter combine monitored the flow rate. GPI meter is self-contained turbine flow sensor with integral battery powered flow computer. The GPI meter is accurate to \pm 0.5 percentage of reading. Pressure was monitored immediately upstream of the nozzle body. Manometer pressure was monitored using a 0-1500 kPa, class $3 \mathrm{~A}$ pressure gauge. The Testo model 454 instrument was used to measure the wind speed, weather conditions, temperature and relative humidity. The anemometer wind, relative humidity and temperature sensor is fixed at the centerline of the nozzles at the $100 \mathrm{~cm}$ from the outlet of the metallic air pipe. The electrical axial fane (Blower) $2.2 \mathrm{~kW}$ was connected at the outlet opening with the flexible air pipe. The flexible air pipe was constructed at the end of the metallic air pipe. The diameter of metallic air pipe is $76.2 \mathrm{~mm}$ and it had 6 hollows. The distance between the hollows is $100 \mathrm{~mm}$ and it is put in the vertical position.

\section{Procedures}

The current research investigates the effect of cross wind that may be produced by the movement of the machine or nature wind on the spray of pattern. The cross-flow of wind are simulated by producing a cross air speed from the electrical axial fane. The electrical axial air fane was setup to produce the cross air speed of 1.2 and $3.1 \mathrm{~m} \mathrm{~s}^{-1}$ under laboratory conditions. The turbulence of air will be negligible for all experiments. The mean treatments for the current study are wind speed, height of nozzles, type of nozzles and pressure nozzles on the spray uniformity distribution. The treatments of cross wind are 3.1, 1.2 and $0 \mathrm{~m} \mathrm{~s}^{-1}$ (with and without wind speeds) and their effect was studied for all nozzles at different height of nozzles and nozzle pressures on spray pattern. The duration of spraying experiments are indicated in table 1. Spray pressures of 300,400 , and $500 \mathrm{kPa}$ are applied under all treatment conditions for the IDKN120-04, AD 110-03 Lechler, TT110-03 Turbo-Jet, and ATR208 nozzle. Three replications are used for every treatment to obtain a high accuracy analysis of results. The arrangement and statistical analysis of the experiments was according to randomized block design. The Hardi sprayer without boom is used as the source of the liquid sprays; the control valves in the sprayer were adjusted the pressure nozzles. The 
single nozzle in boom fixed at middle of the top on the patternator. The single nozzle was used to reduce the overlap that produced at using for several nozzles. The valve that fixed before the single nozzle used to obtain the operating pressure nozzles for every treatment. By operating of the sprayer and the blower, the patterns for every nozzle were measured by the tape and record to analyze the data.

\section{Coefficients of variation (C.V.)}

The coefficients of variation as the percentage of spray pattern for all nozzles treatment were estimated by using the standard equation and excluding the ends where there is no overlap. The coefficient of variation was calculated using the following formula (Herbst, A. and P.Wolf, 2001):

Where $\frac{\sum X_{i}}{n} \ldots . .(1) \quad s=\sqrt{\frac{\sum\left(x_{i}-x^{\prime}\right)^{2}}{n-1}} \ldots \ldots . . .(2) \quad C V=\frac{s}{x^{\prime}} * 100 \ldots \ldots . .(3)$

C.V. the coefficients of variation percentage, $\%$

$\mathrm{x}_{\mathrm{i}}$ the height of liquid in the tube, $\mathrm{cm}$ and,

$\mathrm{n}$ the number of patternator columns

\section{Changes of dose volume $\left(V_{c h}\right)$}

The changes of dose volume $\left(\mathrm{V}_{\mathrm{ch}}\right)$ in the collected tubes due to the effect of wind speed calculated by the equation (4) for all treatment conditions.

$$
\mathrm{V}_{\mathrm{ch}}=\mathrm{V}_{1}-\mathrm{V}_{2}
$$

Where

$\mathrm{V}_{1} \quad$ the volume of spray dose without wind

$\mathrm{V}_{2} \quad$ the volume of spray dose at wind speed

\section{Spray pattern displacement (SPD)}

The following equation (5) from Krishnan et al. (2005) used to calculate the spray pattern displacement (SPD, \%) for all treatment. The present study conducted under relatively consistent temperature conditions in the laboratory, averaging $\left(24{ }^{\circ} \mathrm{C}\right)$ with standard deviation of $\left(0.5^{\circ} \mathrm{C}\right)$. Relative humidity ranged from $58 \%$ to $67 \%$.

$$
S P D=\frac{D_{1}-D_{2}}{D_{2}} \times 100
$$


Table 1: The treatment for different type of nozzles to test the uniformity of spray under laboratory conditions

\begin{tabular}{|c|c|c|c|c|c|c|c|c|c|c|c|c|c|}
\hline \multirow{2}{*}{$\begin{array}{l}\text { Type of } \\
\text { nozzles }\end{array}$} & \multirow{2}{*}{$\begin{array}{c}\text { Nozzle } \\
\text { Pressure, } \\
\mathrm{kPa}\end{array}$} & \multirow{2}{*}{$\begin{array}{l}\text { Nozzle } \\
\text { Height, } \\
\mathrm{cm}\end{array}$} & \multirow{2}{*}{$\begin{array}{c}\mathrm{Q} \\
1 / \mathrm{min}\end{array}$} & \multicolumn{2}{|c|}{ Time } & \multirow{2}{*}{$\begin{array}{l}\text { Wind speed. } \\
\mathrm{ms}^{-1}\end{array}$} & \multirow{2}{*}{$\begin{array}{l}\text { Type of } \\
\text { nozzles }\end{array}$} & \multirow{2}{*}{$\begin{array}{c}\text { Nozzles } \\
\text { Pressure, } \\
\text { kPa }\end{array}$} & \multirow{2}{*}{$\begin{array}{c}\text { Nozzle } \\
\text { height, } \\
\mathrm{cm}\end{array}$} & \multirow{2}{*}{$\begin{array}{c}\mathrm{Q} \\
\mathrm{1} / \mathrm{min} \\
\mathrm{min}\end{array}$} & \multicolumn{2}{|c|}{ Time } & \multirow{2}{*}{$\begin{array}{c}\text { Wind speed } \\
\mathrm{ms}^{-1}\end{array}$} \\
\hline & & & & $\min$ & $\mathrm{s}$ & & & & & & $\min$ & $\mathrm{s}$ & \\
\hline ATR208 & 300 & 30 & 0.87 & 2 & 9 & 0 & TT110-03 & 300 & 30 & 0.81 & 4 & 16 & 0 \\
\hline ATR208 & 300 & 30 & 0.87 & 2 & 9 & 1.2 & TT110-03 & 300 & 30 & 0.81 & 4 & 16 & 1.2 \\
\hline ATR208 & 300 & 30 & 0.87 & 2 & 12 & 3.1 & TT110-03 & 300 & 30 & 0.81 & 4 & 16 & 3.1 \\
\hline ATR208 & 400 & 30 & 0.98 & 2 & 28 & 0 & TT110-03 & 400 & 30 & 0.92 & 3 & 14 & 0 \\
\hline ATR208 & 400 & 30 & 0.98 & 2 & 16 & 1.2 & TT110-03 & 400 & 30 & 0.92 & 3 & 14 & 1.2 \\
\hline ATR208 & 400 & 30 & 0.98 & 2 & 23 & 3.1 & TT110-03 & 400 & 30 & 0.92 & 3 & 34 & 3.1 \\
\hline ATR208 & 500 & 30 & 1.05 & 2 & 24 & 0 & TT110-03 & 500 & 30 & 1.09 & 2 & 30 & 0 \\
\hline ATR208 & 500 & 30 & 1.05 & 2 & 24 & 1.2 & TT110-03 & 500 & 30 & 1.09 & 2 & 40 & 1.2 \\
\hline ATR208 & 500 & 30 & 1.05 & 2 & 20 & 3.1 & TT110-03 & 500 & 30 & 1.09 & 2 & 49 & 3.1 \\
\hline ATR208 & 300 & 60 & 0.87 & 2 & 59 & 0 & TT110-03 & 300 & 60 & 0.91 & 5 & 10 & 0 \\
\hline ATR208 & 300 & 60 & 0.87 & 2 & 59 & 1.2 & TT110-03 & 300 & 60 & 0.91 & 5 & 11 & 1.2 \\
\hline ATR208 & 300 & 60 & 0.87 & 2 & 59 & 3.1 & TT110-03 & 300 & 60 & 0.91 & 5 & 15 & 3.1 \\
\hline ATR208 & 400 & 60 & 0.99 & 3 & 0 & 0 & TT110-03 & 400 & 60 & 1.11 & 4 & 15 & 0 \\
\hline ATR208 & 400 & 60 & 0.99 & 3 & 0 & 1.2 & TT110-03 & 400 & 60 & 1.11 & 4 & 15 & 1.2 \\
\hline ATR208 & 400 & 60 & 0.99 & 3 & 0 & 3.1 & TT110-03 & 400 & 60 & 1.11 & 4 & 15 & 3.1 \\
\hline ATR208 & 500 & 60 & 1.11 & 3 & 0 & 0 & TT110-03 & 500 & 60 & 1.26 & 3 & 1 & 0 \\
\hline ATR208 & 500 & 60 & 1.11 & 3 & 0 & 1.2 & TT110-03 & 500 & 60 & 1.26 & 3 & 7 & 1.2 \\
\hline ATR208 & 500 & 60 & 1.11 & 3 & 5 & 3.1 & TT110-03 & 500 & 60 & 1.26 & 3 & 11 & 3.1 \\
\hline AD110-03 & 300 & 30 & 0.89 & 2 & 57 & 0 & IDKN120-04 & 300 & 30 & 1.22 & 3 & 50 & 0 \\
\hline AD110-03 & 300 & 30 & 0.89 & 2 & 57 & 1.2 & IDKN120-04 & 300 & 30 & 1.22 & 3 & 50 & 1.2 \\
\hline AD110-03 & 300 & 30 & 0.89 & 2 & 45 & 3.1 & IDKN120-04 & 300 & 30 & 1.22 & 3 & 53 & 3.1 \\
\hline AD110-03 & 400 & 30 & 1.09 & 2 & 30 & 0 & IDKN120-04 & 400 & 30 & 1.49 & 1 & 42 & 0 \\
\hline AD110-03 & 400 & 30 & 1.09 & 2 & 30 & 1.2 & IDKN120-04 & 400 & 30 & 1.49 & 1 & 42 & 1.2 \\
\hline AD110-03 & 400 & 30 & 1.09 & 2 & 36 & 3.1 & IDKN120-04 & 400 & 30 & 1.49 & 1 & 47 & 3.1 \\
\hline AD110-03 & 500 & 30 & 1.23 & 2 & 50. & 0 & IDKN120-04 & 500 & 60 & 1.73 & 1 & 32 & 0 \\
\hline AD110-03 & 500 & 30 & 1.23 & 2 & 50 & 1.2 & IDKN120-04 & 500 & 60 & 1.73 & 1 & 32 & 1.2 \\
\hline AD110-03 & 500 & 30 & 1.23 & 2 & 50 & 3.1 & IDKN120-04 & 500 & 60 & 1.73 & 1 & 32 & 3.1 \\
\hline AD110-03 & 300 & 60 & 0.92 & 5 & 10 & 0 & IDKN120-04 & 300 & 60 & 1.22 & 2 & 43 & 0 \\
\hline AD110-03 & 300 & 60 & 0.92 & 5 & 10 & 1.2 & IDKN120-04 & 300 & 60 & 1.22 & 2 & 43 & 1.2 \\
\hline AD110-03 & 300 & 60 & 0.92 & 5 & 17 & 3.1 & IDKN120-04 & 300 & 60 & 1.22 & 2 & 43 & 3.1 \\
\hline AD110-03 & 400 & 60 & 1.11 & 4 & 15 & 0 & IDKN120-04 & 400 & 60 & 1.48 & 3 & 21 & 0 \\
\hline AD110-03 & 400 & 60 & 1.11 & 4 & 15 & 1.2 & IDKN120-04 & 400 & 60 & 1.48 & 3 & 21 & 1.2 \\
\hline AD110-03 & 400 & 60 & 1.11 & 4 & 17 & 3.1 & IDKN120-04 & 400 & 60 & 1.48 & 3 & 21 & 3.1 \\
\hline AD110-03 & 500 & 60 & 1.26 & 3 & 1 & 0 & IDKN120-04 & 500 & 30 & 1.72 & 3 & 0 & 0 \\
\hline AD110-03 & 500 & 60 & 1.26 & 3 & 1 & 1.2 & IDKN120-04 & 500 & 30 & 1.72 & 3 & 0 & 1.2 \\
\hline AD110-03 & 500 & 60 & 1.26 & 3 & 17 & 3.1 & IDKN120-04 & 500 & 30 & 1.72 & 3 & 0 & 3.1 \\
\hline
\end{tabular}


Whereas

SPD the spray pattern displacement, \%

$\mathrm{D}_{1} \quad$ the total distance of spray pattern under the nozzles with effect of wind, cm and,

$\mathrm{D}_{2} \quad$ the total distance of spray pattern under the nozzles without effect of wind, $\mathrm{cm}$

The high values of spray pattern displacements percent (SPD \%) is the indicator for low uniformity distribution of spray pattern.

easure the distribution of nozzles

\section{RESULTS AND DISCUSSIONS}

\section{The uniformity distribution}

The Coefficients of variation for all treatments are given in Tables 2, 3 and 4. From the statistical analysis of these parameter data, it was shown that spray distribution is improved by increasing nozzle size, pressure and reduces the nozzle height. The type of nozzles is very important parameters which affect the distribution of pattern (C.V.) values as shown in Table 2.

Table 2: Effect of the nozzles and the height of nozzles on the coefficient of variation percentage

\begin{tabular}{|c|c|c|}
\hline Type of nozzles & Nozzle height, cm & $\mathrm{CV}, \%$ \\
\hline ATR208 & 30 & 17.6 \\
\hline ATR208 & 60 & 19.1 \\
\hline AD110-03 & 30 & 11.6 \\
\hline AD110-03 & 60 & 13.9 \\
\hline TT110-03 & 30 & 11.8 \\
\hline TT110-03 & 60 & 13.8 \\
\hline IDKN120-04 & 30 & 8.0 \\
\hline IDKN120-04 & 60 & 8.6 \\
\hline
\end{tabular}

The interaction between nozzles type nozzle pressures was significant at 5 $\%$ level. This is probably due to the behavior of nozzles of different spray angels. The low value of coefficient of variation represents an indicator for good uniformity distribution. 
Table 3: Effect of the nozzles and the pressure nozzles on the coefficient of variation percentage

\begin{tabular}{lcc}
\hline Type of nozzles & $\begin{array}{c}\text { Nozzle } \\
\text { pressure, kPa }\end{array}$ & $\begin{array}{c}\text { Coefficient of } \\
\text { variation (C.V.), \% }\end{array}$ \\
\hline ATR208 & 300 & 20.3 \\
ATR208 & 400 & 18.6 \\
ATR208 & 500 & 16.1 \\
AD110-03 & 300 & 15.2 \\
AD110-03 & 400 & 11.7 \\
AD110-03 & 500 & 11.2 \\
TT110-03 & 300 & 13.4 \\
TT110-03 & 400 & 13.2 \\
TT110-03 & 500 & 11.9 \\
IDKN120-04 & 300 & 8.9 \\
IDKN120-04 & 400 & 8.4 \\
IDKN120-04 & 500 & 7.6 \\
\hline
\end{tabular}

\section{LSD at $5 \% \quad 0.119204$}

The IDKN110-04 nozzle gave the better uniformity distribution compared to TT1100-03 Turbo-Jet, AD110-03 Lechler, and ATR208 Albus nozzles because it produced the greater size of droplet. The coefficient of variation percentage $(\mathrm{CV}, \%)$ value was $7.2 \%$ for IDKN110-04 nozzle at $500 \mathrm{kPa}$ nozzle pressure and $30 \mathrm{~cm}$ nozzle height. The ATR208 nozzle gave $21.3 \%$ coefficient of variation percentage at $300 \mathrm{kPa}$ and $30 \mathrm{~cm}$. The selection of nozzles may be reduced the losses of spray dose and gives good distribution of pattern.

The interaction between the type of nozzle and the nozzle pressure indicated that, the increasing of nozzle pressure tends to decrease the spray pattern for all different types of nozzles as shown in Table $\mathbf{3}$ and Fig. 3. The operating nozzle pressure of $500 \mathrm{kPa}$ gave the $7.6 \%$ coefficient of variation percentage for IDKN11004 nozzle compared to low pressure $(300 \mathrm{kPa})$ which gave $20.3 \%$ coefficient of variation percentage for ATR208 Albus nozzle. As well as, the effect of the interaction of the type of nozzle and nozzle height was indicated in Table 2. The increasing of nozzle height tends to reduce the uniformity distribution of spray. 


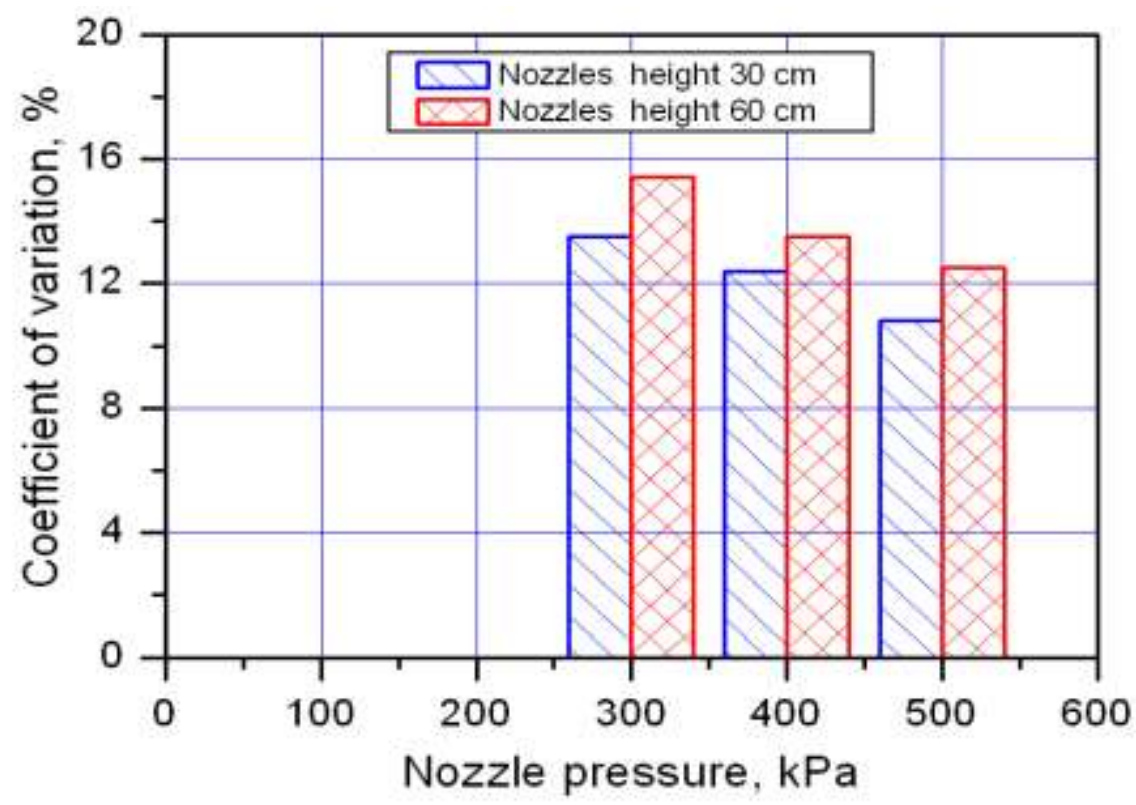

Fig. 3: Effect of the nozzle height and the nozzle pressures on the coefficient of variation percentage

The IDKN110-04 nozzle gave the better uniformity distribution at $30 \mathrm{~cm}$ nozzle height. The C.V. values were $8 \%$ and $19.1 \%$ for IDKN110-04 and ATR208 (Albus) nozzle respectively. On the other hand, it noticed that there was no difference of coefficient variation percentage between the AD110-03 and TT110-03 nozzle, therefore, the two nozzles had the same size. The effects of wind speed on the spray pattern are given in Fig. 4.

The high value of wind speed $\left(3.1 \mathrm{~m} \mathrm{~s}^{-1}\right)$ tends to increase the (C.V., \%) compared to the wind speeds ( 0 and $1.2 \mathrm{~m} \mathrm{~s}^{-1}$ ) at all nozzles height and nozzle pressures. The $30 \mathrm{~cm}$ nozzle height tends to decrease the coefficient of variation; it gave the good uniformity distribution compared to $60 \mathrm{~cm}$ nozzles height. The effect of the interaction of wind speed, nozzle pressures, and nozzle height was non-significant probably. In addition, the wind speed was non-significant effect on the CV percentage at low height of nozzles $(30 \mathrm{~cm})$ compared to the height of nozzles $(60$ $\mathrm{cm})$. The increase of the height of nozzles tends to increase the losses of spray at the constant pressure nozzles. 


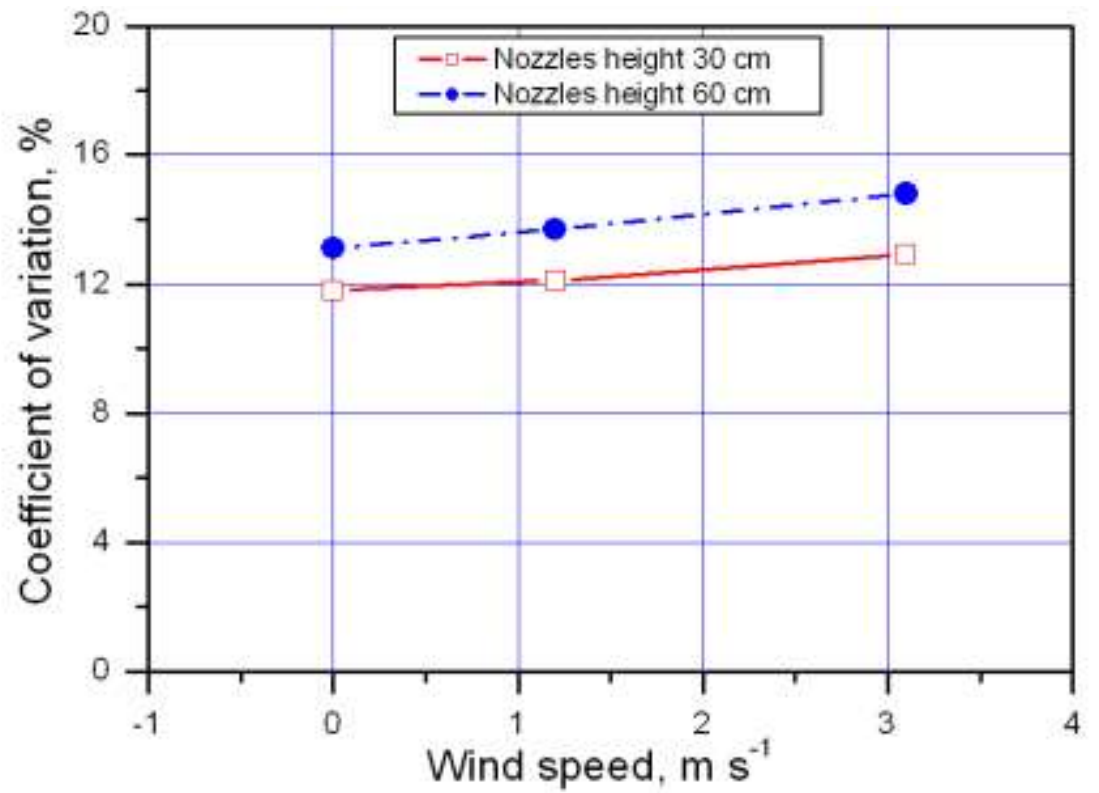

Fig. 4: The interaction of the effect of the height of nozzles Effect of the

\section{Change in dose volume} nozzle height and wind on the coefficient of variation percentage

The change in dose volume $\left(\mathrm{V}_{\mathrm{ch}}\right)$ for all treatments under this current study were calculated and indicated in Fig. (5 a, b, c and d) and (6 a, b, c and d). The ATR208 Albus holly cone gave the highest values of the change in dose volume compared to the AD110-03, TT110-03 and IDKN120-04 nozzles. Therefore, the ATR208 Albus holly cone nozzle produced the holly cone spray trajectory compared to the flat trajectory of spray for the nozzles of AD110-03, TT110-03 and IDKN120-04. It means also that the losses of spray will be more for ATR208 nozzle than that for the other nozzles. The effect of wind speed on the change of dose volume was highly significant effect for the ATR208 nozzles compared to the AD110-03, TT110-03, and IDKN120-04 nozzles. The increasing of nozzle pressure tends to reduce the change in dose volume for all different nozzle types. As well as, the decrease of the height of nozzles tends to reduce the change of dose volume at wind speed of $3.1 \mathrm{~ms}^{-1}$ for all different types of nozzle. The nozzle height of $60 \mathrm{~cm}$ gave a significant effect and higher values of the change of dose pattern compared to the 30 $\mathrm{cm}$ nozzle height as shown in Fig. (5 a, b, c, and d). 
The interaction between the type of nozzle and the nozzle pressure indicate that the increasing of nozzle pressure tends to decrease the change in dose volume $\left(\mathrm{V}_{\mathrm{ch}}\right)$ as shown in Fig. (5 a, b, c and d) and (6 a, b, c, and d). The operating nozzle pressure of $500 \mathrm{kPa}$ gave the low change in dose volume $\left(\mathrm{V}_{\mathrm{ch}}\right)$ for IDKN11004 nozzle compared to low pressure of $300 \mathrm{kPa}$ which gave the greatest values of the change in dose volume for ATR208 (Albus) nozzle. As well as, the effect of the interaction of the type of nozzle and nozzle height was indicated in Fig. (5 a, b, $\mathbf{c}$ and $\mathbf{c})$ and $(5 \mathbf{a}, \mathbf{b}, \mathbf{c}$ and $\mathbf{c})$. The increasing of nozzle height tends to reduce the change in dose volume. The IDKN110-04 nozzle gave the low change in dose volume at $30 \mathrm{~cm}$ nozzle height.

The effects of wind speed on the change in dose volume are given in Fig. 4. The high value of cross-flow $3.1 \mathrm{~m} \mathrm{~s}^{-1}$ tends to increase the change in dose volume compared to the low wind speed $0 \mathrm{~m}$ and $1.2 \mathrm{~m} \mathrm{~s}^{-1}$ wind speed at all height of nozzles and nozzles of pressure. The $30 \mathrm{~cm}$ nozzle height tends to decrease the change in dose volume compared to $60 \mathrm{~cm}$ nozzles height. The effect of the interaction of wind speed, nozzle pressures, and nozzle height was non-significant probably. Also, the wind speed was non significant effect on the change in dose volume at low height of nozzle of $(30 \mathrm{~cm})$ compared to the height of nozzles of $(60 \mathrm{~cm})$ for the AD110-03, TT110-03, and IDKN120-04 nozzles as shown in Fig. $(5 \mathrm{~b}, \mathrm{c}$, and d) and (6 b, c, and d).

\section{Spray pattern displacements (SPD \%)}

The results for spray pattern displacements percent (SPD \%) parameter for all nozzles were indicated in Fig. 7, 8, 9 and 10. The type of nozzles and the height of boom and nozzle pressure effect on the spray displacements percentage, which produced due to the effect of cross wind speed. The wind speed of $1.2 \mathrm{~m} \mathrm{~s}^{-1}$ was non-significant effect on the SPD $\%$ at $30 \mathrm{~cm}$ height of nozzles as shown in Fig. 7 and 9 for all different type of nozzles. This result was agreed to Gabriilides, (1965). On the other hand, the wind speed of $3.1 \mathrm{~m} \mathrm{~s}^{-1}$ was significant effect on the SPD percentage at $60 \mathrm{~cm}$ height of nozzles for all type of nozzles as shown in Fig. 8 and 10. The nozzle height of $60 \mathrm{~cm}$ gave the high values of the SPD percentage values compared to the nozzle height $30 \mathrm{~cm}$. It means the $60 \mathrm{~cm}$ that nozzle height gave the lowest uniformity 
distribution. Therefore the wind speed will be more affected at the higher nozzle height than that the lower setting nozzle height. The results of the interaction of wind speed and height of nozzle types for all nozzles at same pressure of nozzle were a highly significant effect on SPD percentage. The increasing of wind speed and height of nozzles tend to increase the SPD percentage.

The SPD \% for ATR208 Albus holly cone nozzle at both heights of boom 30 and $60 \mathrm{~cm}$ were higher than the SPD percentage values for the AD11003, TT110-03 Tee-jet, and IDKN120-04 at same operating nozzle pressure of 300 and $400 \mathrm{kPa}$. It is noticed that the increasing of nozzle pressure tend to reduced the SPD percentage for all different of nozzles. This results due to the increasing of the kinematics energy of the droplets by increasing of the liquid nozzles pressure. The AD110-03 Lechler nozzle affected by the increasing of cross wind, pressure and nozzle height as shown in Fig. 7, 8, 9 and 10. On the other hand, the TT110-03 Tee-jet nozzle and IDKN110-04 gave a non-significant effect compared to the ATR208 and AD110-03 nozzles. The mean SPD percentage values at wind speed of $1.2 \mathrm{~m} \mathrm{~s}^{-1}$ were 8.1 and $11.1 \%$ at nozzle height of 30 and $60 \mathrm{~cm}$ for pressure of $300 \mathrm{kPa}$ and ATR 208 nozzle respectively. Also the mean SPD percentage values at wind speed of $3.1 \mathrm{~m} \mathrm{~s}^{-1}$ were 12.6 and $17.1 \%$ at nozzle height of 30 and $60 \mathrm{~cm}$ for nozzle pressure of $300 \mathrm{kPa}$ and ATR 208 nozzle respectively. AS well as, the minimum SPD \% values were $0.8 \%$ and $1.24 \%$ at wind speed $1.2 \mathrm{~m} \mathrm{~s}^{-1}$ and $3.1 \mathrm{~m} \mathrm{~s}^{-1}$ respectively at nozzle height $30 \mathrm{~cm}$ and pressures $300 \mathrm{kPa}$ for IDKN11003 nozzle. In addition, the minimum SPD percentage values were $2 \%$ and $3.27 \%$ at wind speed $1.2 \mathrm{~m} \mathrm{~s}^{-1}$ and $3.1 \mathrm{~m} \mathrm{~s}^{-1}$ respectively at nozzle height $r 0 \mathrm{~cm}$ and pressures of nozzle $r 00 \mathrm{kPa}$ for IDKN110-03 nozzle. On the other hand, the maximum SPD \% values were $17.1 \%$ at the ATR 208 nozzle, nozzle height of $60 \mathrm{~cm}$, wind speed of $3.1 \mathrm{~ms}^{-1}$ and nozzle pressure of $300 \mathrm{kPa}$. In addition, the maximum SPD for the other nozzles at nozzle height of $60 \mathrm{~cm}$, wind speed of $3.1 \mathrm{~ms}^{-1} 3.1$ and nozzle pressure $300 \mathrm{kPa}$ were $10.3,7.9$, and $5.8 \%$ for the AD110-03, TT110-03 Tee-jet and IDKN110-04 nozzle respectively. 
Table 4: Effect of the interaction for nozzle types, nozzle height, and the nozzle pressures on the on the coefficient of variation percentage

\begin{tabular}{lccc}
\hline $\begin{array}{c}\text { Type of } \\
\text { nozzles }\end{array}$ & $\begin{array}{c}\text { Nozzle } \\
\text { height, } \\
\text { cm }\end{array}$ & $\begin{array}{c}\text { Nozzle } \\
\text { pressure, } \\
\text { kPa }\end{array}$ & $\begin{array}{c}\text { Coefficient of } \\
\text { variation }(\mathbf{C . V . )}, \boldsymbol{\%}\end{array}$ \\
\hline ATR208 & 30 & 300 & 19.3 \\
ATR208 & 30 & 400 & 18.8 \\
ATR208 & 30 & 500 & 14.7 \\
ATR208 & 60 & 300 & 21.3 \\
ATR208 & 60 & 400 & 18.4 \\
ATR208 & 60 & 500 & 17.6 \\
AD110-03 & 30 & 300 & 14.2 \\
AD110-03 & 30 & 400 & 10.4 \\
AD110-03 & 30 & 500 & 10.2 \\
AD110-03 & 60 & 300 & 16.3 \\
AD110-03 & 60 & 400 & 13.0 \\
AD110-03 & 60 & 500 & 12.3 \\
TT110-03 & 30 & 300 & 11.7 \\
TT110-03 & 30 & 400 & 12.5 \\
TT110-03 & 30 & 500 & 11.2 \\
TT110-03 & 60 & 300 & 15.1 \\
TT110-03 & 60 & 400 & 13.9 \\
TT110-03 & 60 & 500 & 12.7 \\
IDKN120-04 & 30 & 300 & 8.7 \\
IDKN120-04 & 30 & 400 & 8.1 \\
IDKN120-04 & 30 & 500 & 7.2 \\
IDKN120-04 & 60 & 300 & 9.0 \\
IDKN120-04 & 60 & 400 & 8.8 \\
IDKN120-04 & 60 & 500 & 7.9 \\
\hline \multicolumn{1}{|c|}{ LSD at $5 \%$} & 0.168580 & & \\
& & & \\
\hline
\end{tabular}


[a]

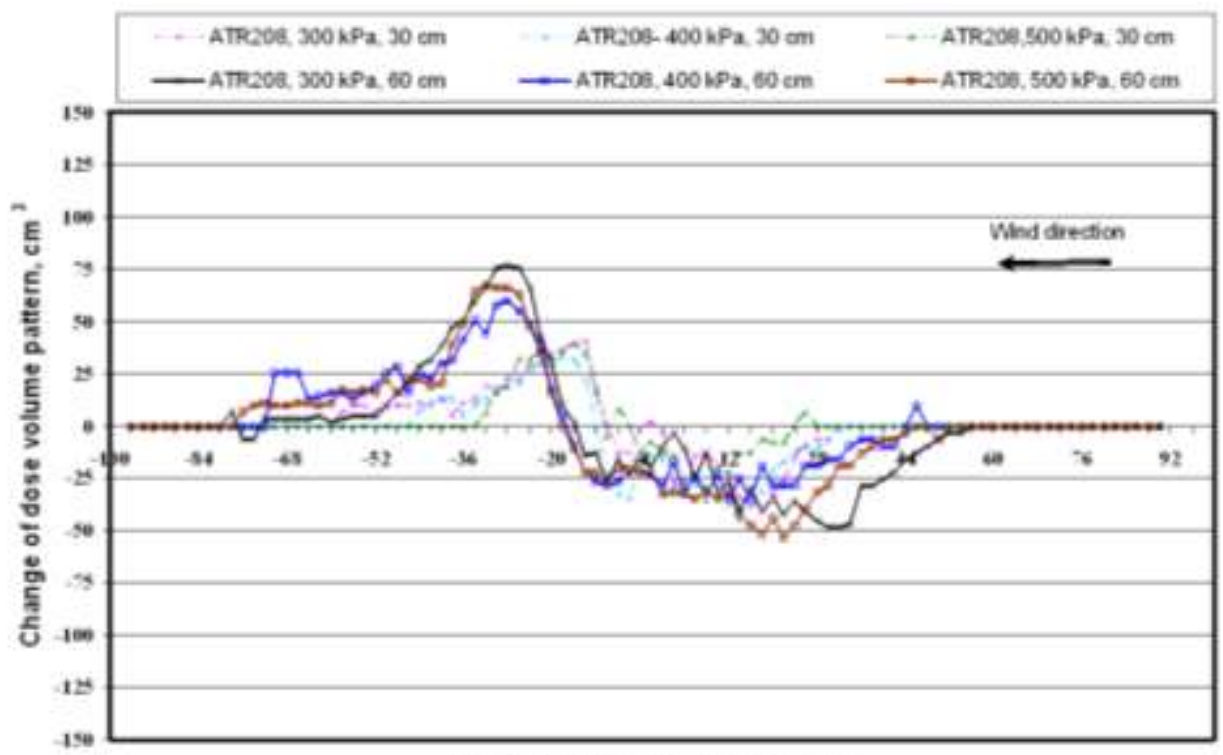

Distance from nozzle center, $\mathrm{cm}$

[b]

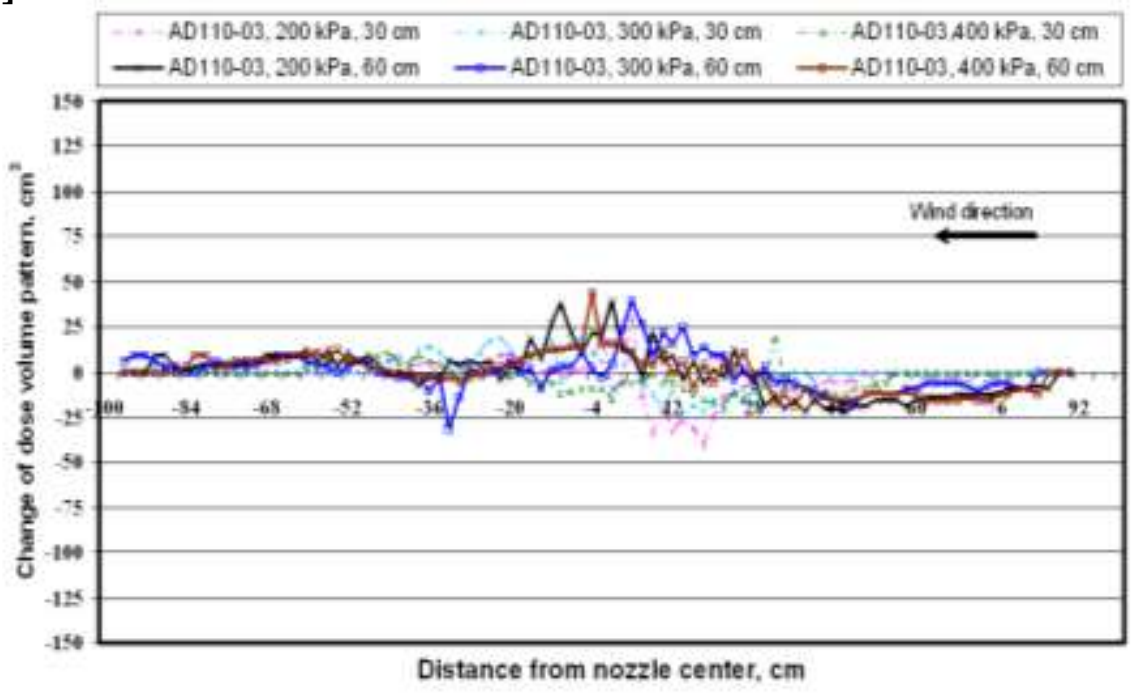

Fig. (5 a and b): Change of dose volumes pattern due to the wind speed for all nozzles and at two different nozzle height of $30 \mathrm{~cm}$ and $60 \mathrm{~cm}$ and $1.2 \mathrm{~m} \mathrm{~s}^{-1}$ wind speed 
[c]

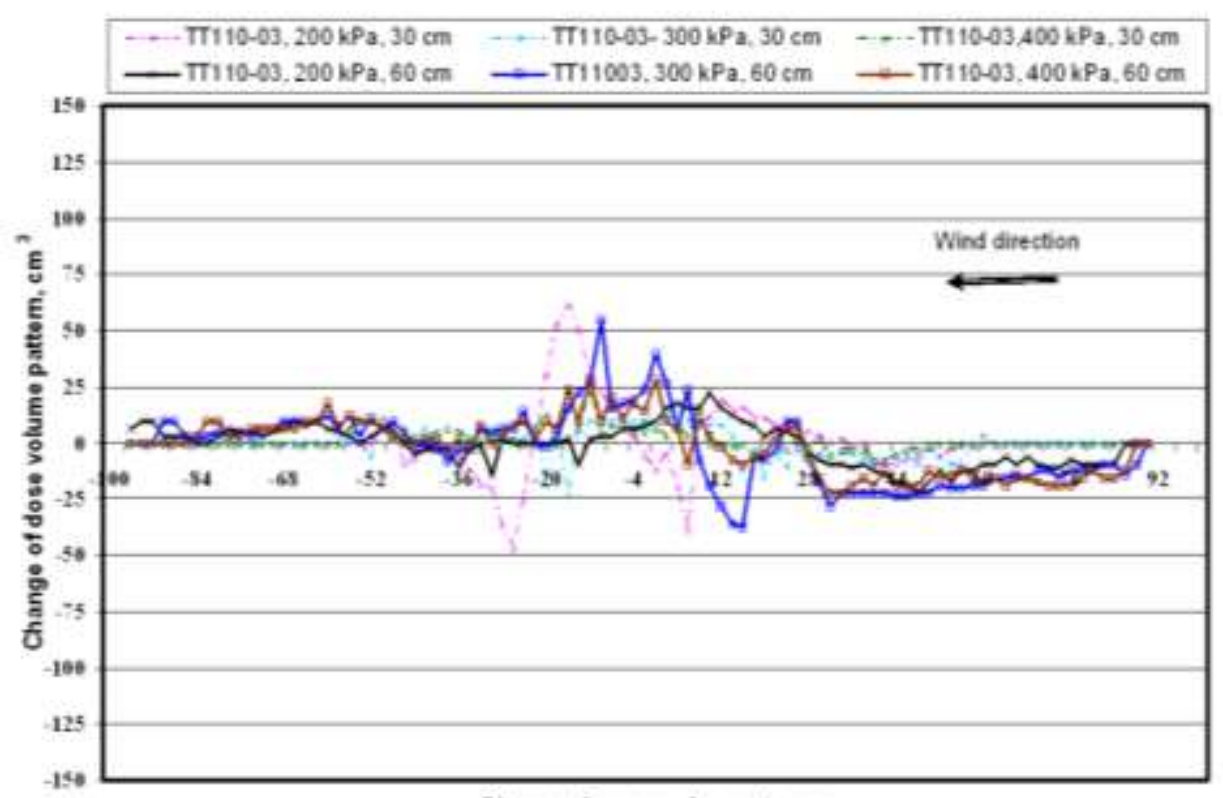

Distance from nozzle center, cm

[d]

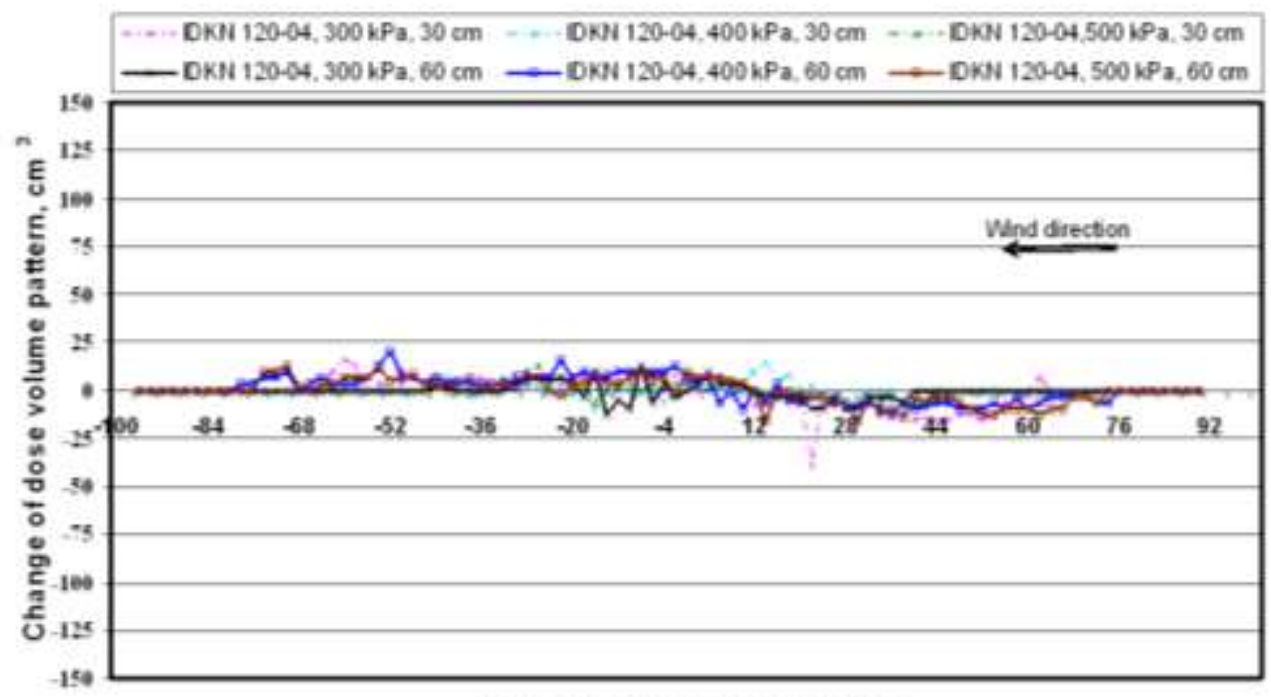

Distance from nozzle center, $\mathrm{cm}$

Fig. (5 c and d): Change of dose volumes pattern due to the wind speed for all nozzles and at two different nozzle height of $30 \mathrm{~cm}$ and $60 \mathrm{~cm}$ and $1.2 \mathrm{~m} \mathrm{~s}^{-1}$ wind speed 
[a]

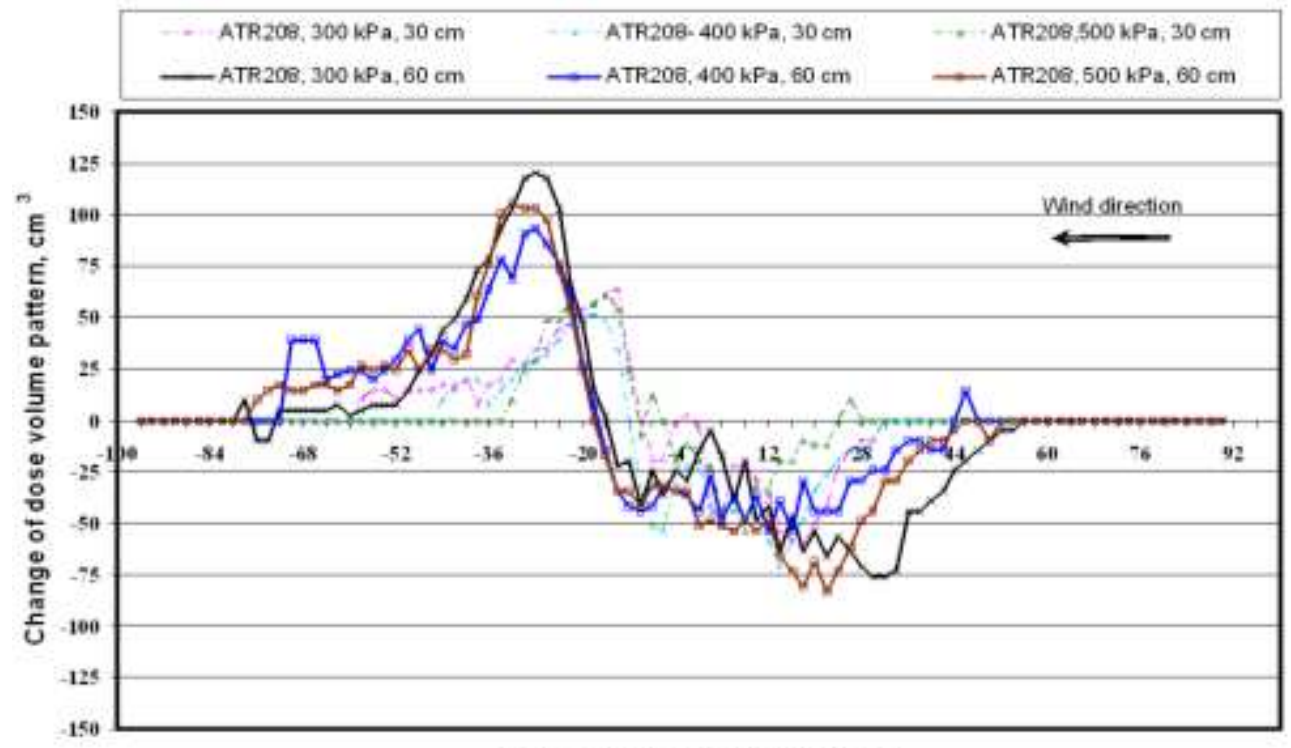

Distance from nozzle center, cm

[b]

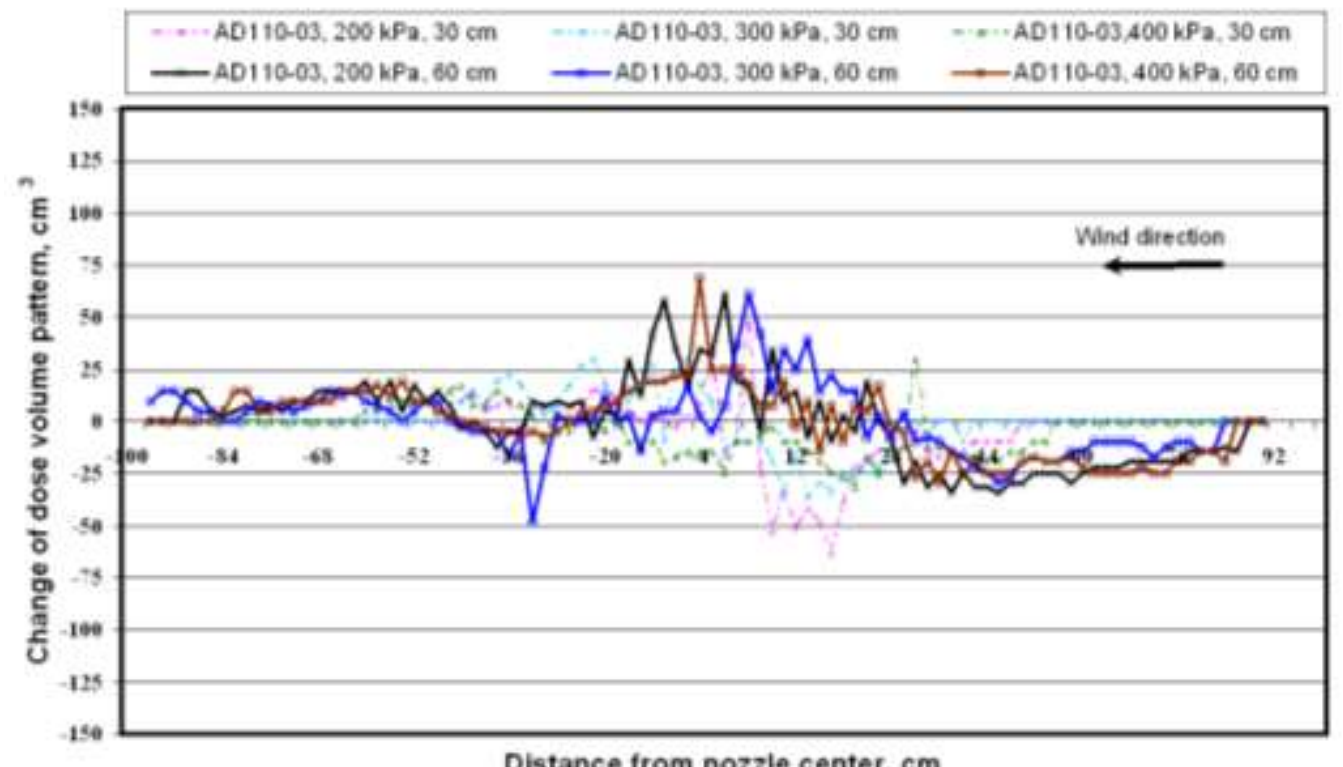

Fig. (6 a and b): Change of dose volumes pattern due to the wind speed for all nozzles and at two different nozzle height of $30 \mathrm{~cm}$ and $60 \mathrm{~cm}$ and $3.1 \mathrm{~m} \mathrm{~s}^{-1}$ wind speed 


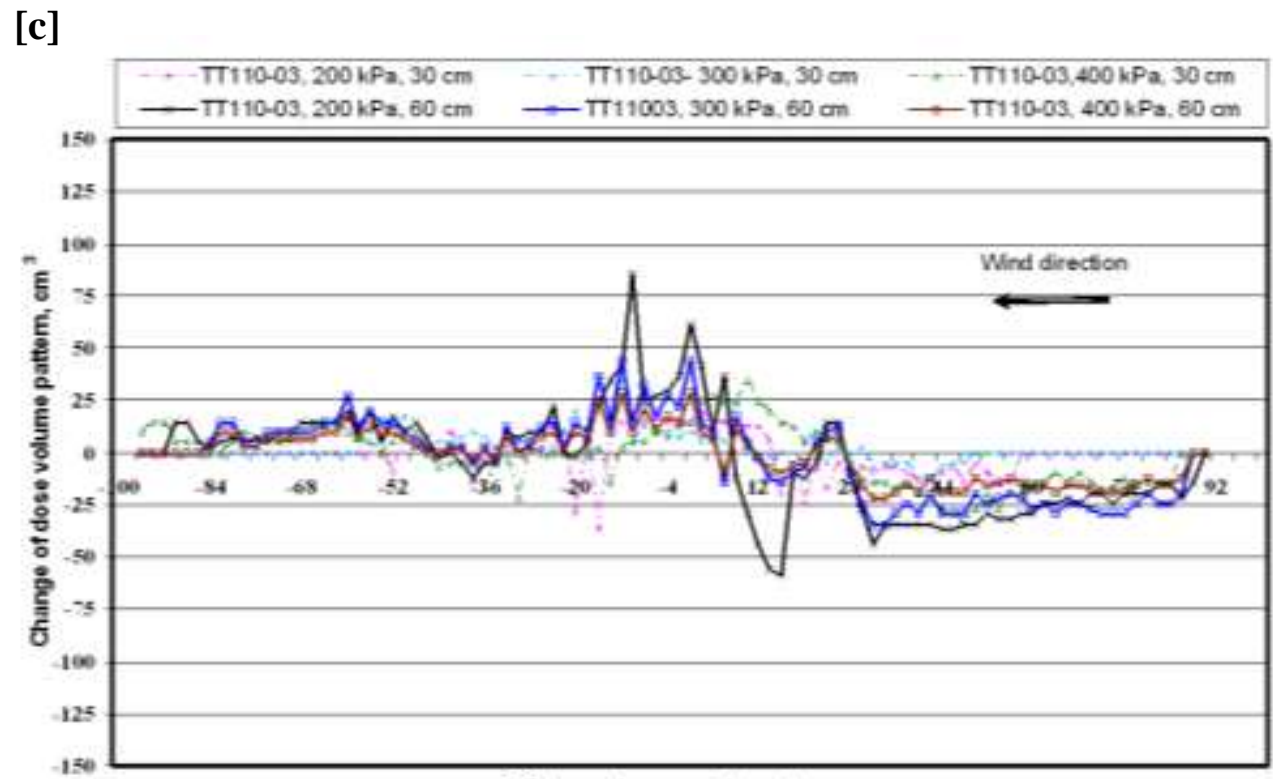

Distance from nozzle center, $\mathrm{cm}$

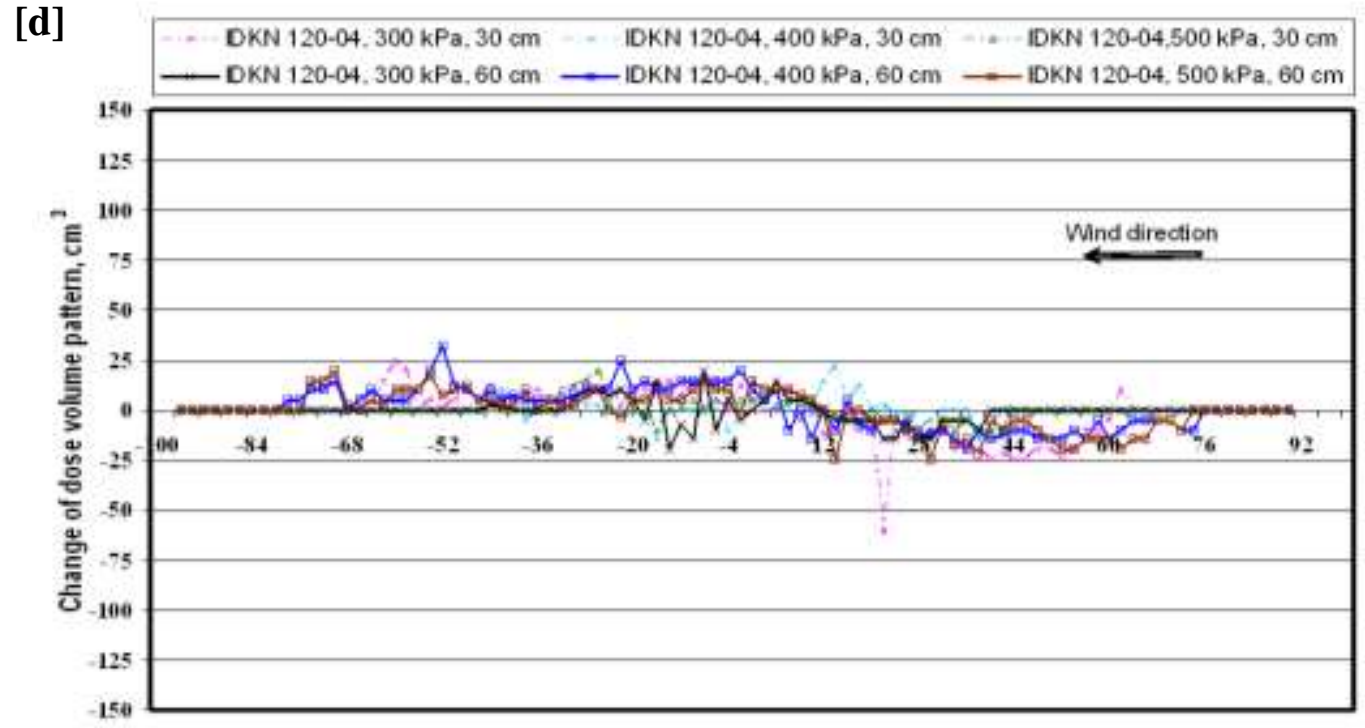

Distance from nozzle center, $\mathrm{cm}$

Fig. (6 c and d): Change of dose volumes pattern due to the wind speed for all nozzles and at two different nozzle height of $30 \mathrm{~cm}$ and $60 \mathrm{~cm}$ and $3.1 \mathrm{~m} \mathrm{~s}^{-1}$ wind speed 


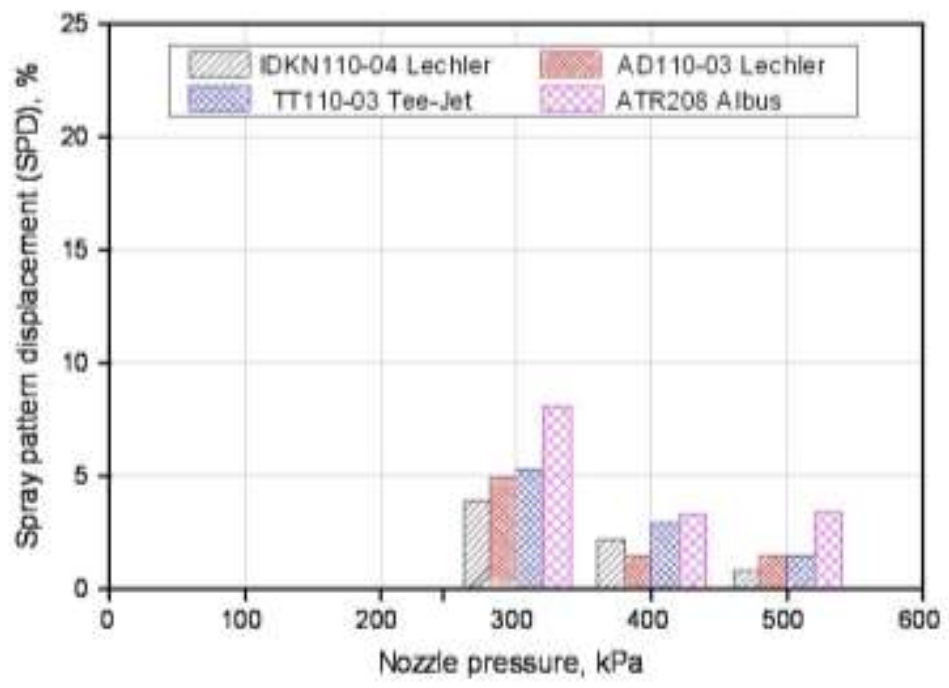

Fig. 7: Spray pattern displacement for IDKN 110-04, AD110-03 Lechler, TT110-03 Tee-jet and ATR 208 nozzles at $30 \mathrm{~cm}$ height of nozzles and $1.2 \mathrm{~m} \mathrm{~s}^{-1}$ wind speed

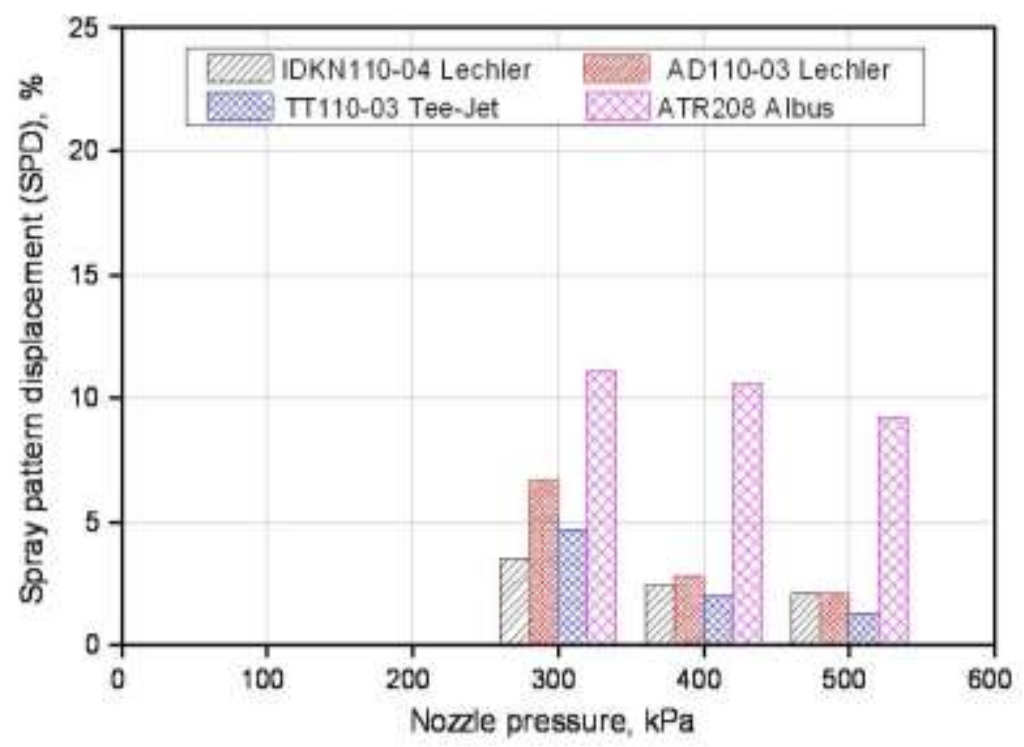

Fig. 8: Spray pattern displacement for IDKN 110-04, AD110-03 Lechler, TT110-03 Tee-jet and ATR208 Albus nozzles at $60 \mathrm{~cm}$ height of nozzles and $1.2 \mathrm{~m} \mathrm{~s}^{-1}$ wind speed 


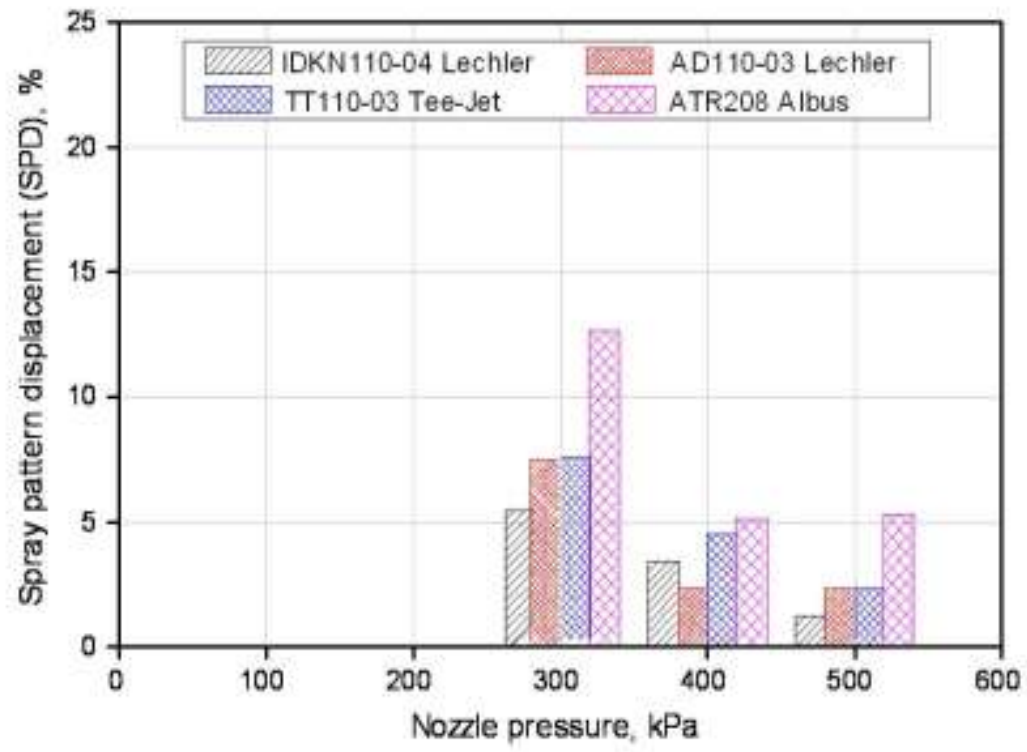

Fig. 9: Spray pattern displacement for IDKN 110-04, AD110-03 Lechler, TT110-03 Tee-jet and ATR 208 nozzles at $30 \mathrm{~cm}$ height of nozzles and $3.1 \mathrm{~m} \mathrm{~s}-1$ wind speed

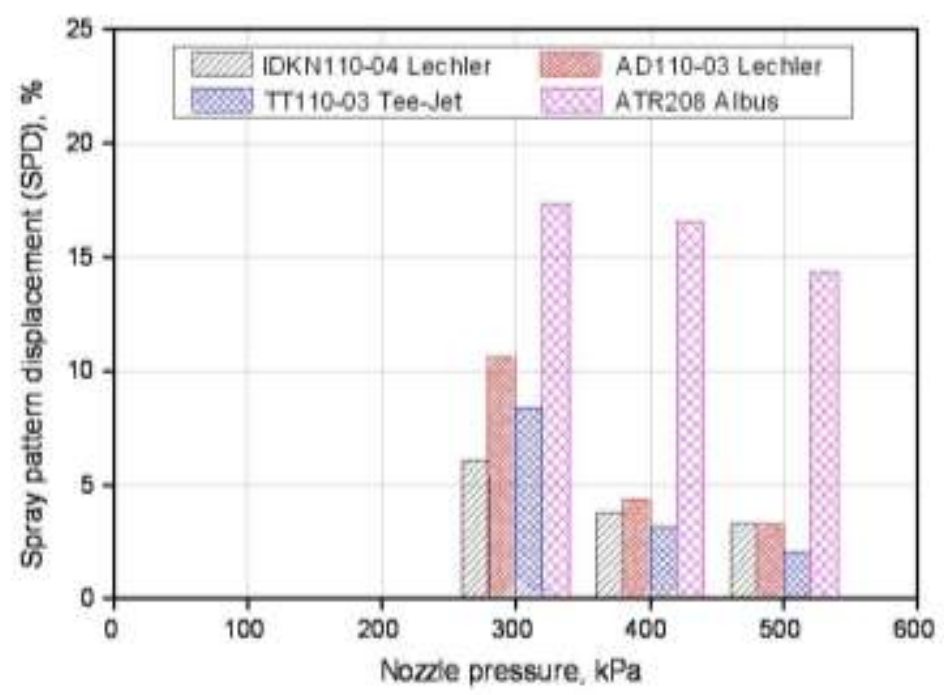

Fig. 10: Spray pattern displacement for IDKN 110-04, AD110-03 Lechler, TT110-03 Tee-jet and ATR 208 nozzles at $60 \mathrm{~cm}$ height of nozzles and $3.1 \mathrm{~m} \mathrm{~s}-1$ wind speed 


\section{CONCLUSION}

The results indicated that the wind speed, nozzle pressure, and height of nozzles affect the spray uniformity distribution. The IDKN120-04 gave the lowest values of the spray pattern for SPD \%, $\mathrm{V}_{\mathrm{ch}}$ and (C.V., \%) values compared to the AD110-03 and TT110-03 nozzles. On the other hand, the interactions of nozzle height and nozzle pressure under wind speed affected the spray pattern. The decreasing of nozzle height tends to increase the uniformity of spray and the coverage of spray dose. As well as, the increasing of nozzle pressure under wind condition, tend to give the good uniformity of dose. To reduce the effecting of wind speed (cross-flow), it should be increasing the pressure of nozzles and reducing the boom of height if possible to do. On the other hand, it could be used a spraying with a shielded sprayer, it is done in row crops to keep pesticides away from crops that would otherwise be injured. As well as, selection the nozzles that produce very low values for SPD, $\mathrm{V}_{\mathrm{ch}}$ and (C.V., \%).

\section{REFERENCES}

Briffa, F. E. J., and N. Dombrowski (1966). Entrainment of air into a liquid spray. Am. Inst. Chem. Eng. J.12: 708-717.

Gabriilides, S.Th. (1965). Distribution patterns in low pressure hydraulic sprays. JAER,10 (1):10-14.

Ghosh, S. and J. C. R. Hunt (1998). Spray jets in a cross-flow J. Fluid Mech., 365: 109-136. (Printed in the United Kingdom)

Herbst, A. and P. Wolf (2001). Spray deposit distribution from from agricultural boom sprayers in dynamic conditions. ASAE Meeting Paper 01-1054.

Holland, J. M; P. C. Jepson, E. C. Jones and C. Turner (1997). 'A comparison of spinning disc atomisers and flat fan pressure nozzles in terms of pesticide deposition and biological efficacy within cereal crops.' Crop Protection, 16: 179 - 185.

Koch, H.; and P. Weisser (1996). Dosierung und Applikationsqualitat bei Verwendung einer Laborspritzbahn in der Prüfung von Pflanzenschutzmitteln., Nachrichtenbl. Deut. Pflanzenschutz, 48.: $176-180$. 
Krishnan P., L. J. Kemble, and I.Gal (2005). Dynamic spray pattern displacement of extended range fan nozzles. Applied Engineering in Agriculture. 21(5): 751-753.

Nordbo, E. (1992). Effects of nozzle size, travel speed and air assistance on deposition on artificial vertical and horizontal targets in laboratory experiments. Crop Protection, 11: 272 - 278.

Nordbo, E.; and W.A. Taylor (1991). The effect of air assistance and spray quality (drop size) on the availability, uniformity and deposition of spray on contrasting targets. BCPC Mono 46: 113 124.

Ozkan, H. E.; D. L. Reichard; and J. S. Sweeney (1992a). Droplet size distribution across the fan patterns of new and worn nozzles. Trans of the ASAE, 35 (4): 1097 - 1102.

Ozkan, H. E.; D. L., Reichard; and K. D. Ackerman (1992b). Effect of orifice wear on spray patterns from fan nozzles. Trans of the ASAE, 35 (4): $1091-1096$.

Richards, M. D; E. C., Hislop; and N. M. Western (1997). Static and dynamic patternation of hydraulic pressure nozzles. Aspects of Applied Biology, 48: 201 - 208.

Richardson, B.; W. C.Schou; and M. O. Kimberley (2000). Defining acceptable levels of spray deposit variation from aerial herbicide applications. ASAE Meeting Paper 00 -1054.

Richardson, R.G.; J.H., Combellack; and L. Andrews (1985). Evaluation of a spray nozzle patternator. Crop Protection, 5: 8-11.

Ringel, R; W. A. Taylor; and P. G. Andersen (1991). Changing spray deposits from horizontal to vertical surfaces at ground level within cereal rows using air assistance. BCPC Mono 46: 297 - 298.

\section{Acknowledgments}

The authors wish to acknowledge all staff member in the Institute of Agricultural Engineering, University of Hohenheim, Germany for their help. In addition, we would like to thank Dr.Robart Heinkel from Lechler Co. in Germany for his support. 


\section{عبرعلا صخلملا}

\section{دراسة بعض العوامل المؤثرة على انتظامية توزيع الرش}

د.السيد محمود البيلى صحصاح و أ.د. ذيجفريد كليذنجر

تهدف هذه الدر اسة التى تم أجر ائها بمعهد الهندسة الزر اعية بجامعة هو هنهايم بالمانيا الى البحث

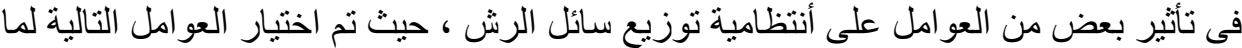

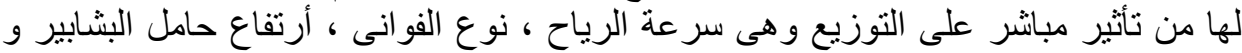

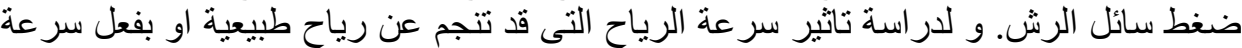

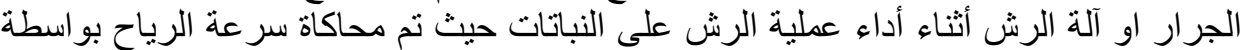

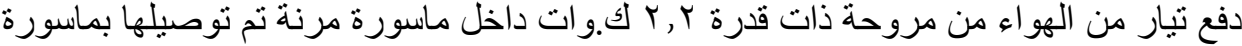

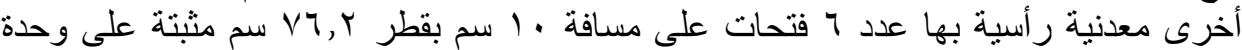

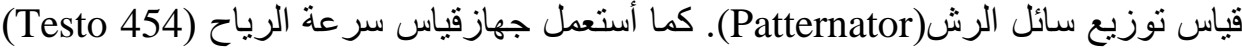

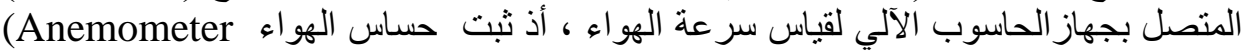

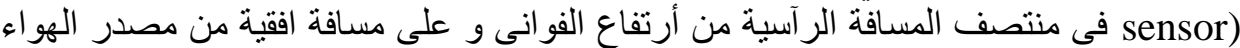

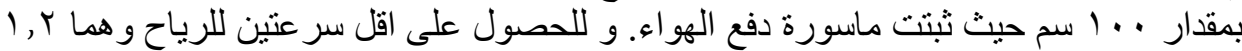

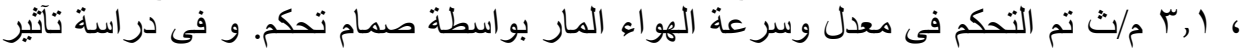

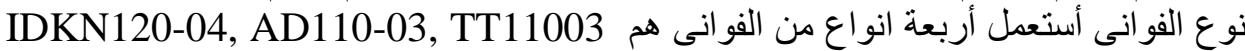
Turbo Jet nozzle , ATR208 Albus.

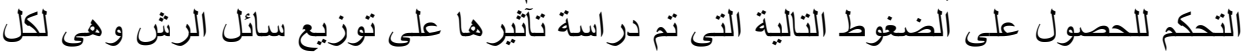

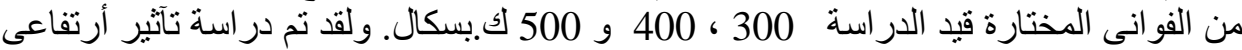

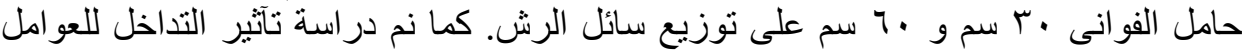

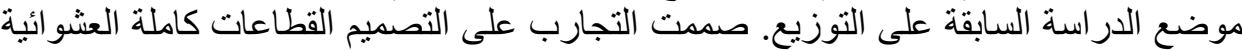
حيث أستعمل ثناث مكرر ات لكل معاملة من معاملات التجات التهارب.

قبيل دفع تيار الهو اء اى عند سر عة صفر م/ث شغلت وحدة الرش آى المكنونة من خزان الرش

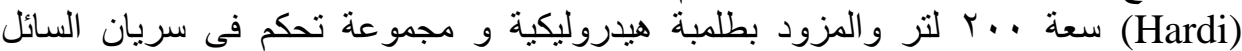

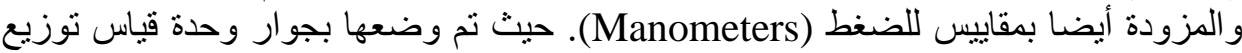

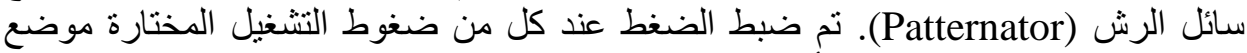

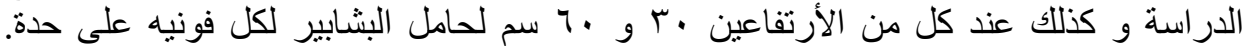

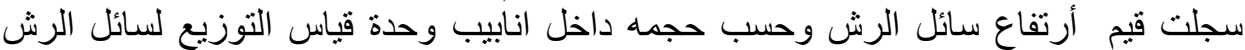

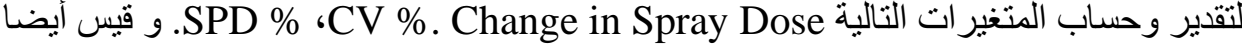

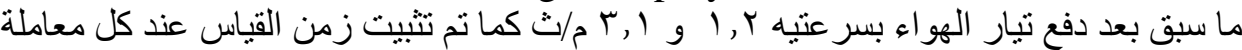

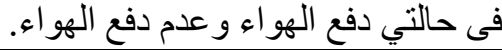

* مدرس بقسم الهندسة الزر اعيةـ كلية الزر اعة- جامعة كفر الثيخ- مصر. ** أستاذ بمعهد الهندسة الزر اعية- جامعة هو هنهايم- ألمانيا. 
و لقد اتضح من النتائج المتحصل عليها ان سرعة الرياح لها تآثير معنوى على نسبة معامل

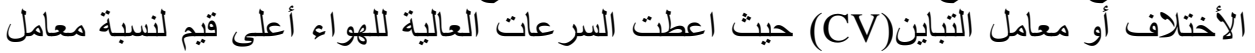

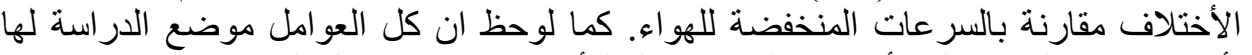

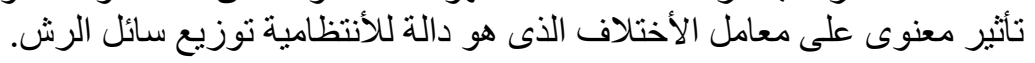

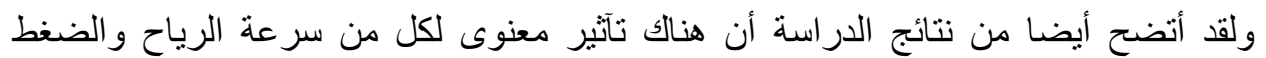

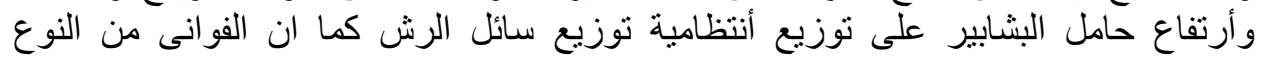

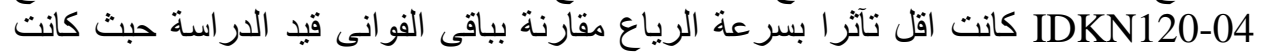

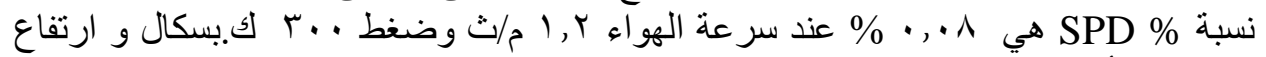

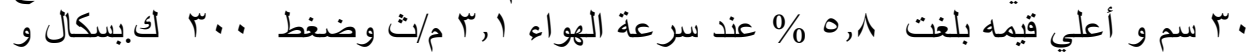
ارتفاع • آ سم لحامل البشابير.

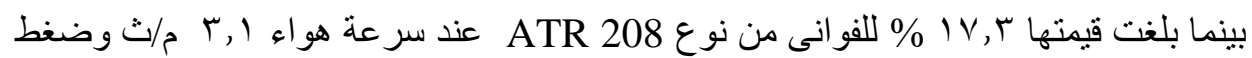

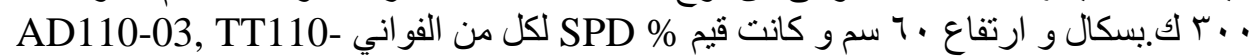

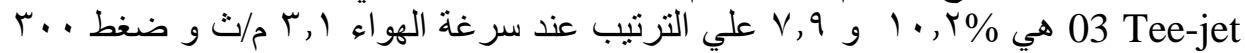

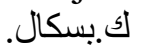

